\section{'Southern Home': An Interspecific Hybrid Grape with Ornamental Value}

\author{
J.A. Mortensen ${ }^{1}$ J.W. Harris ${ }^{2}$, and D.L. Hopkins ${ }^{3}$ \\ Central Florida Research and Education Center, University of Florida, 5336 \\ University Avenue, Leesburg, FL 34748
}

\section{P.C. Andersen ${ }^{4}$ \\ North Florida Research and Education Center, University of Florida, Route 4 Box 63, Monticello, FL 32344}

Additional index words. Vitis, fruit breeding, ornamental, disease resistance
'Southern Home' (Vitis rotundifolia Michx., V. munsoniana Simpson ex Munson, $V$. popenoei Fennell, V. vinifera L.) (Rogers and Mortensen, 1979) is being released by the Univ. of Florida as an ornamental, backyard grape with adaptability to the southern United States. Black muscadine cultivars being planted around homes have little, if any, ornamental value. However, this interspecific hybrid (part bunch grape and part muscadine) is unique in appearance because of its leaf shape, which has deep-cut sinuses, resembling that of a maple leaf. It has potential as a home gardener's grape that could be grown on arbors around patios and as borders on fences throughout the southern United States.

Because of its superior disease resistance, few, if any, fungicide applications are required, making 'Southern Home' environmentally compatible with the move toward reduced pesticide usage around the home. It is everbearing, producing ripe fruit from midAugust through October or November in Florida.

\section{Origin}

'Southern Home' originated from the grape breeding program at the Central Florida Research and Education Center in Leesburg. 'Southern Home' was one of 43 seedlings from a 1979 cross between 'Summit' ( $V$. rotundifolia) and Fla. P9-15 (Fig. 1). 'Summit' produces female flowers and large, bronze fruit with fair texture and good flavor (Mortensen and Andrews, 1981). Fla. P9-15 produces medium-sized, black, elongated berries that have a tough texture but good aromatic flavor. The vine of Fla. P9-15 is a hermaphroditic interspecific hybrid with good

Received for publication 22 Feb. 1994. Accepted for Agricultural Experiment Station Journal Series paper no. R-03680. The cost of publishing this paper was defrayed in part by the payment of page charges. Under postal regulations, this paper therefore must be hereby marked advertisement solely to indicate this fact.

${ }^{1}$ Professor Emeritus.

${ }^{2}$ Senior Lab Technician.

${ }^{3}$ Professor.

${ }^{4}$ Associate Professor publication 21 June 1994. University of Florida disease resistance. Florida P9-15 originated as a self of Z67-7-5, which resulted from a cross between 'Farrer 30' and Fennell's three-way hybrid female, $V$. popenoei $\times(V$. rotundifolia $x$ V. munsoniana). 'Farrer 30', when traced back to the original cross between V39- $\mathrm{R}_{2}-\mathrm{B}_{2}$ (V. rotundifolia) female and 'Black Morocco' (V. vinifera) in 1916, makes 'Southern Home' six generations removed from $V$. vinifera (Fig. 1) and is thus heavily muscadine in its traits. The original seedling of 'Southern Home' was planted in the vineyard in 1981 and fruited in 1984. It was first selected in 1984 because of its striking leaf pattern, unique fruit, vigor, and disease resistance and was propagated for further trial as Fla. AA12-3.

\section{Description}

'Southern Home' has excellent vine vigor, with semi-recumbent growth and 4- to 12-cmlong internodes. Leaves average $10 \mathrm{~cm}$ in length and $11 \mathrm{~cm}$ in width, resembling a maple leaf with deeply cut sinuses that are bilaterally convex in shape (Fig. 2). Abaxial leaf surfaces are light green and shiny, with very slight white pubescence, noticeable mainly at vein junctions. Adaxial leaf surfaces are dark green and shiny with a slightly rugose appearance on the outer margins of leaves. Petioles are shorter than leaf blade midribs, and the petiolar sinus is open. Tendrils are discontinuous along nodes and unbranched. Anthocyanin pigmentation appears in petioles, lower leaf surface veins, tendrils, and newly expanded shoots and leaves.

Flowers are perfect. Primary fruit may be found on the fourth and fifth nodes of the shoot, while occasional fruit may be found on the third node. Clusters are moderately loose, averaging 12.2 berries per cluster. Berries are oval, black, and weigh $10 \%$ to $20 \%$ less than the other cultivars tested (Table 1). Fruit usually begin ripening at Leesburg $\approx 15$ Aug. Berries within clusters ripen uniformly, with a few late clusters ripening into October or November. Ripe fruit of 'Southern Home' can adhere to the vine for longer periods than that of regular muscadine cultivars. Lenticels are more prominent on 'Southern Home' berries than on 'Alachua'. With 3.4 seeds per berry weighing $5.6 \mathrm{~g} / 100$ seeds, there is an average flesh : seed ratio of 33:1. This favorable ratio is similar to that of 'Alachua', at 30:1. Pulp texture is similar to that of 'Cowart' or 'Albemarle' and breaks up easily when chewed. The picking scar is moderately dry, and the soluble solids concentration is equal to or higher than that of the other black muscadine cultivars tested.

Symptoms of Pierce's disease have never been observed in 'Southern Home' at Leesburg (Mortensen et al., 1977). The absence of fruit rot during 5 years of observation demonstrates that 'Southern Home' is highly resistant to ripe rot [Glomerella cingulata (Stonem) Spaulding \& Von Schrenk], bitter rot [Melanconium fuligineum (Scrib. \& Viala) Cav.], and black rot [Guignardia bidwellii (Ell.) Viala \& Ravaz]. It is also highly resistant to anthracnose [Elsinoe ampelina (de Bary) Shear] and downy mildew [Plasmospara viticola (B \& C) Berl. \& de T.], as are most true muscadines. Late-season diseases such as angular leaf spot (Mycosphaerella angulata Jenkins) may occur on 'Southern Home' but in such small amounts that fungicide application may not be warranted. Its insect resistance is similar to that of typical muscadine cultivars. 'Southern Home' likely will not need a regular preventive fungicidal or insecticidal spray program, except in areas of extremely severe disease pressure.

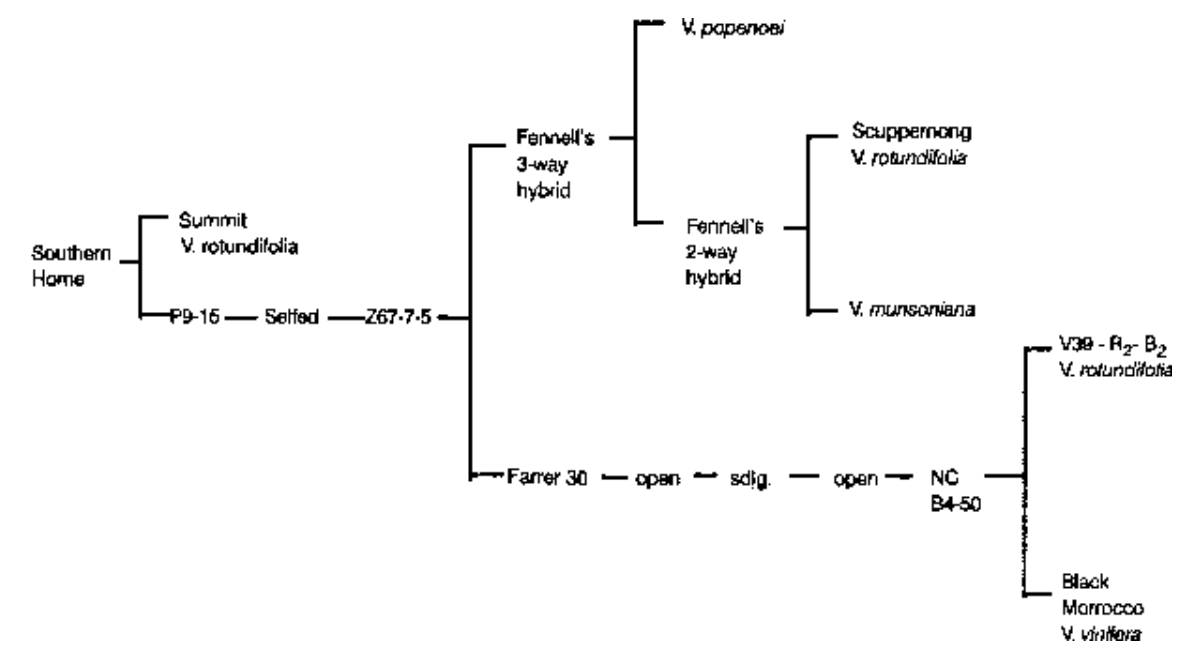

Fig. 1. Pedigree of 'Southern Home'. 


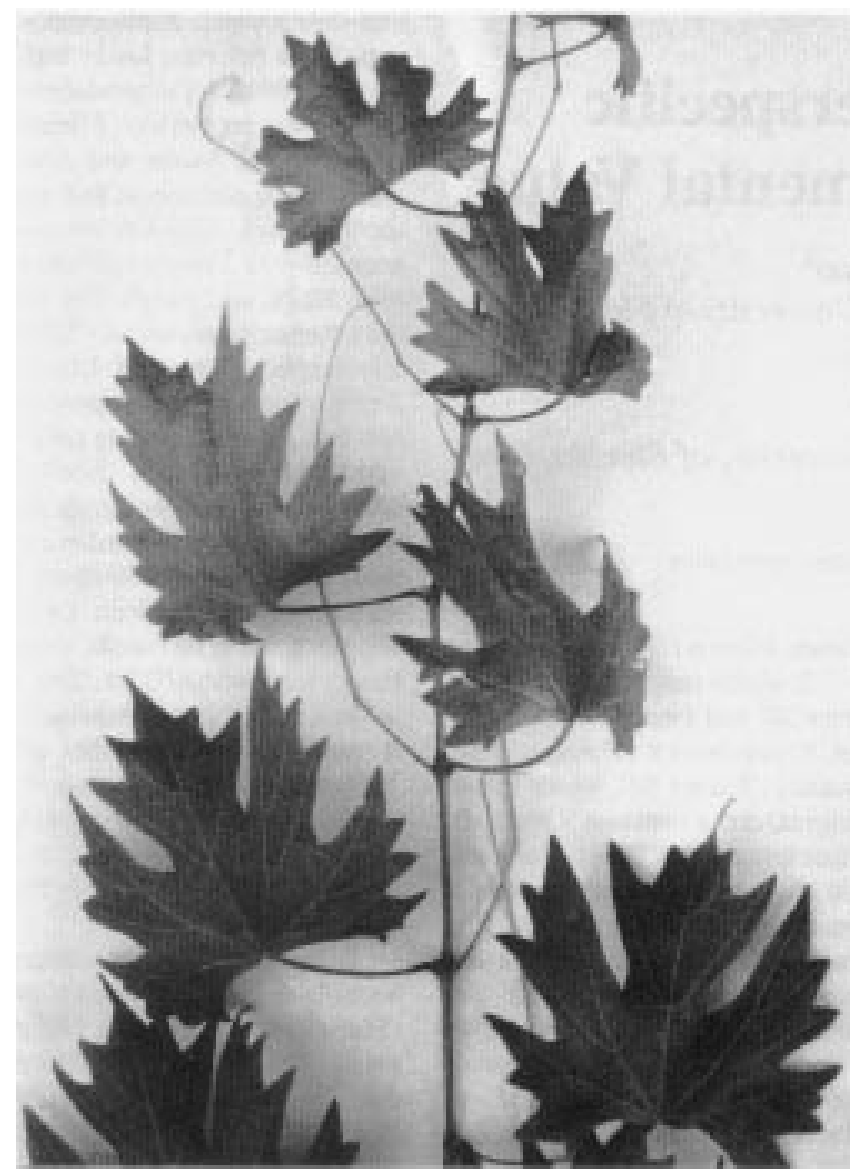

Fig. 2. Foliage of 'Southern Home'.

Table 1. Fruit attributes of 'Southern Home' compared with other black muscadine cultivars at Leesburg and Monticello, Fla. ${ }^{2}$

\begin{tabular}{|c|c|c|c|c|}
\hline Cultivar ${ }^{y}$ & $\begin{array}{c}\text { Fruit with } \\
\text { dry scar } \\
(\%)\end{array}$ & $\begin{array}{c}\text { Berry } \\
\text { wt } \\
(\mathrm{g})\end{array}$ & $\begin{array}{c}\text { Soluble } \\
\text { solids } \\
\text { concn } \\
(\%)\end{array}$ & $\begin{array}{l}\text { Type of } \\
\text { ripening }\end{array}$ \\
\hline \multicolumn{5}{|c|}{ Leesburg } \\
\hline Southern Home & $62.0 \mathrm{a}$ & $6.8 \mathrm{~b}$ & $19.0 \mathrm{a}$ & Even \\
\hline Alachua & $72.9 \mathrm{a}$ & $7.6 \mathrm{~b}$ & $18.3 \mathrm{ab}$ & Even \\
\hline Nesbitt & $26.0 \mathrm{~b}$ & $10.2 \mathrm{a}$ & $16.9 \mathrm{~b}$ & Uneven \\
\hline \multicolumn{5}{|c|}{ Monticello } \\
\hline Southern Home & 97.5 & 6.8 & 19.1 & $--^{x}$ \\
\hline Alachua & 98.0 & 8.0 & 17.7 & -- \\
\hline Loomis & 70.0 & 9.8 & 15.1 & --- \\
\hline
\end{tabular}

${ }^{2}$ Data in the Leesburg tests are the means for 5 years and represent 30 samples per year for dry scar and berry size and five samples per year for soluble solids. Data from the Monticello tests are for 1 year and represent 20 samples. For the Leesburg tests, mean separation within columns is by the Duncan's multiple range test, $P \leq 0.05$.

${ }^{y}$ All are perfect and self-fertile.

${ }^{\mathrm{x}}$ Not tested.
'Southern Home' propagates readily from herbaceous cuttings under mist in June and July and does not require grafting. 'Southern Home' is adapted to well-drained soils of Florida. To our knowledge, no data are available as to its performance on bedded soils in flatwood areas. Winter hardiness is good in Florida, but has not been tested in other southern states.

Unpasteurized juices from 'Southern Home' have turned brown rapidly in tests at Leesburg, indicating that it may be unsuitable as a wine cultivar. However, it may be suitable for juice and jellies. In 1991, 'Southern Home' received taste panel ratings of "moderate" when compared to seven muscadine cultivars. This rating may have resulted from the unique aromatic flavor that differs from typical muscadines with which it was compared.

'Southern Home' interspecific hybrid grape is recommended for dooryard and ornamental purposes. The principal advantages of 'Southern Home' are its unique leaf shape and vigor, making it useful as an ornamental cultivar that could be used on arbors, around patios, and as borders on fences. It has excellent disease resistance, perfect flowers (no pollinizer cultivar needed), desirably high soluble solids concentration, uniform cluster ripening, and the everbearing characteristic.

\section{Availability}

A plant patent is pending on 'Southern Home', and inquiries regarding a license for propagation should be directed to Florida Foundation Seed Producers, P.O. Box 309, Greenwood, FL 32443.

\section{Literature Cited}

Mortensen, J.A. and C.P. Andrews. 1981. Grape cultivar trials and recommended cultivars for Florida viticulture. Proc. Fla. State Hort. Soc. 94:328-331.

Mortensen, J.A., L.H. Stover, and C.F. Balerdi. 1977. Sources of resistance to Pierce's disease in Vitis. J. Amer. Soc. Hort. Sci. 102:695-697.

Rogers, D.J. and J.A. Mortensen. 1979. The native grape species of Florida. Proc. Fla. State Hort. Soc. 92:286-289. 